Limnological Studies of The Tachiyazawa-gawa

(Yamagata Prefecture)

-Limnological Studies of The Rivers around Mt. Gassan. 2-

\title{
Takeo KATō
}

In this paper, the results of the investigations of the Tachiyazawagawa are reported. The results are summarised as follows :-

1. The water temperature of the river is lower than that of the Mogami (main stream) throughout the snow-melting season. The difference lies 1.3 and 5.1 .

2. The upper reaches of the river consist of the Nigorisawa, the Honsawa (the main stream) and the Akasawa. Among the three, the Nigorisawa is most influenced by the volcanic activity of Mt. Gassan, judging from the chemical analysis of the water taken from the stations in the drainage system.

3. The content of the dissolved oxygen in the water undergoes the diurnal change. The relation between the oxygen content and the water temperature nearly shows the negative correlation.

4. The chloride content of the river decreases regularly with the increase of the flow except during the snow-melting season.

* Institute of Chemistry, Faculty of Education, Yamagata University.

\section{紹介および批評}

\section{中国地域杜会研究会編：大根島一生態と課題}

A 5 判, 402 頁, 関書院. 京都. 1956 年刊

松江市の東方，夜見ケ浜と島根半島にかこまれた中海の中に，大小 2 つの玄武岩 からなる台地状の火山島がある. 大きい方が大根島，小さい方が江島と呼ばれるこ の 2 島によって，島根県八束郡八束村が構成されている．大根島という書名をもつ 
たこの共同調査報告書は，実は江島をも含めた八束村全体を取り扱つているのであ るが，ダイコン島という名前は，我々をほほえませるアトラクティヴなひびきをも つている. もつともこの島の特産は, 決して大根ではなくて，人参，しかも薬用人 参 (朝鮮人参) である．その他，まゆと中海の魚が，この島の商品経済を支える支 柱である.この島の人口密度は約 1000 人，村の人口密度としては県下随一，それ だけに人口過剩国日本の縮図ともいうべき島であり，県内第 1 位の養腽村でもある. だが，まゆと人参とは，国際的な価格変動が極めてはげしい商品であるだけに，こ の島は時には「島だれ」といわれる程の貧困におち入り，また時には「金の生る島」 と美望されるほどの富裕さをも示すはげしい盛衰をくりかえして来たのであつた。 そして，このような浮沈のはげしさは，上部構造にも深刻な影響を与え，特定の人

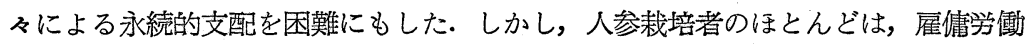
に依存する富農層であり，また養盁農家も，一部中農層を含むとはいえ，島民の 1 割程度にすぎない，多くの島民は，人参からも，まゆからも見放され，更に中海水 産資源の涸渴に，深刻な䇞機を感じている，離島と異なつて，早くから商品経済に まき込まれているだけに，この島には，別の深刻な矛盾がひそんでいるのである. 昭和 26 年以来, 島根大学の山岡栄市教授 (社会学) を中心に，3 人の地理学者（草 光繁・岩永実・庄司人孝の 3 氏）が，主力を構成する中国地域社会研究会が，4力 年以上に亘つて，この島の実熊の究明に取組んで来られたのも，このような特色を もつた島だつたからであつた。

さて本書は前・後篇の 2 部に分れる. 前篇ではまづ第 1 章で, 農・漁民の生活, 周辺地域との交渉, 人口压, 生活水準の 5 つの視角から, 問題提起がなされた後, 自然(草光繁) ・集落・政治・産業と経済・社会と民俗・教育と文化の 6 章に分けて， 各論が展開されている. 重点は経済と社会に扔かれ，ことに経済の章（第 5 章）で は，戸口と職業構成（岩永実）, 島の経済発達の歩み（庄司久孝・内藤正中）, 農地 改革と漁業制度（山岡栄市）と力作がならび，山岡氏の社会集団の解明と共に，本 書中の白眉といつて差支えない，なかでも，岩永氏は精緻な考証を基碟にした，精 力的な論述を進められ，草光氏また生活と密着した形で，極めて手ぎわよく，自然 的諸要因を説明していられる，後篇は，江戸時代の村落構造・入会問題・現在の過 剩人口についての特論である．前篇が現状とその史的背景についての，多面的な考 察であるのに対し，後篇はこの各論を基礎として，特殊な視点から，綜合的に考察 された総括を意図して書かれたものであろう（特に過剩人口）. 最後にあとがきと して，故老との座談会の記録と研究経過，それに資料目録を付してある.

中国地域社会研究会がかくも長年月に亘り，しかも相当広い分野に亘る専門家を 動員しつつ，一系乱れぬ強固な団結を以て，この調査報告を完成されたことには， 敬服のほかはない，その意味で，現段階における模範的な共同調査といつて差支え 
ないであろう.とはいえ，これを以て私は理想的な共同調查というには，いささか 躊躇せざるをえない，私自身，なお幾つかの問題が残されていることを感じるから だある・

第 1 に，この調査報告は前・後篇の 2 部に分たれている. 庄司教授に伺つた構想 によると，これは特論と総括を意図されたもののようである.だがその構想は，果 して実現されているであろうか. 結果的には，後篇は特論で論じ洩らされた若干の 問題点補遺に終つているようである. その点，後篇の部分は，前篇中に収められな いことはなかつたと，思われるのであつて，むしろ後篇は，やはり各論によつて提 起された諸論点を整理し，再分析して，これにはつきりした理論的体彔を与えると 共に，将来への展望を行う場所としていただきたかつたと思う．本書の副題一一生 態と課題一一後者は，かくてはじめて，生命を与えられただろうからである.

第 2 に，前篇の各論執筆者相互間で，資料の相互提供と調整が，スムースに行わ れていることは，極めてすぐれた特色であつて，諸学科が連合した時によく見られ る，学問セクトを打破できていない同床異夢的な名ばかりの共同調査と，全く違つ た点であるが，諸論考の間に，質的な差がなお残り，まだ併列的な感じがすること も事実である.もちろん同程度に進んた問題意識と，学問的水準をもつ研究者を， 全分野において最初から揃えることは，特定の地域内においては至難のわざであろ ろが，もし調査が常に真劍な討議を基礎として行われ，更に編集権が確立されてい るならば，各章の不均衡の是正は不可能ではないはずである. 特にこれは, 教育と 文化の項に，あてはまるのである.

第 3 に編集者の遠慮がちな態度は，執筆者に対してだけでなく，村当局に対した 場合にも見られ，村政の分析がかなり甘くなつている. そしてこれが，全体の統一 性を不十分ならしめた，1つの原因になつているようである.つまり，基本的な立 場が，章によつて違つているように見うけられる，たとえば島内最大の人参畑の経 営者が，潜在的失業人口に就労の場を与えているという表現と，半封建的土地所有 が島民にとつて大きな桎梏であつたという記述とは，一体どのように結びつけられ るのであろうか。もちろん我及の考察は，あくまでも具体的事実に立脚した実証性 をもたねばならないが，それは理論的一貫性を軽視する理由には，ならないはずで ある・

第 4 にこの報告は，だれを目標に書かれたのであろうか. 各章で文章の表現が， 多少まちまちになつていることも事実である，文体だけでなく，記述の方式につい ても，なお古い郡村誌的残㳯が残つている章があるのは，目ざわりである。こうい つた点も，編集者の手で統一していただきたかつた。できるならば，島の人々にわ かる言葉と表現を使つて，より高い内容を盛つていただきたかつたと思う。なお全 体として，相当重複している箇所があり，全体から見て不必要な表やグラフも，ま 
ざつているようであるが，これを思いきつて削除していただいたすが，一層すつき りしたものになつたと思う。

以上，尊敬する諸先学の方々に対し，非礼をも顧みず，若干の苦言を，思いつく ままに申し上げたが，しかしそれは，本畫がまれに見る緊密なチームワークの上に 築き上げられた，すぐれた調查報告であることを，少しも損ねるものではない。た だ今後，一層チームワークを緊密化していただくと共に，共通の問題意識を一層深 め，編集権を確立して，より高い成果を挙げていただくことを熱望する余り，申し 上げただけであると共に，ここに呈した苦言は，私たち岡山において共同調查に従 事している者にとつても，今後の方向を義務ずける，自責自戒の鞭であることも申 しそえて㭧こう。

河野 通博

\section{瀬戸内海総合研究会編 : 山村の生活}

\section{一岡山県苫田郡富村大一}

432 頁，地図 2 葉，写真図版多数，付録，別表 1袋，1955 年

岡山大学に本拠をおく瀬戸内海総合研究会は，岡山県の村落についてすでに「農 村の生活」(1951 年)，「漁村の生活」(1954 年) を刊行したが，ここに第 3 輯とし て本畫を出し， 3 部作を完結した。このような村落の調査にあたつては，まず調査 部落の選定が問題となるが，耕種生産額が 5 割以下，やや孤立的で都市化の少ない こと，戸数 40〜50 の小部落であること，近世史料の豊富に残つていること等を考 慮し，さらに地元の理解と援助が得られ，また十数名の合宿調査のできることなど， 種々調査の上，この大部落が決定された。調査参加者は自然科学関係では，動物学， 地質学，林学，畜産学，建築学で計 7 名，医学班の住宅調査（環境衛生） 8 名，医 学的諸調查 19 名であり, 社会科学関係では歴史学 2 名, 農業経済学 2 名, 教育学 2 名, 文化人類学・民族学各 1 名とともに，人文地理学は喜多村俊夫，河野通博， 由比浜省吾，石田寛の 4 君がいる. 調査は 52 年 3 月下゙旬と 5 月上旬の 2 回，医学 班は 8〜9月に行い，調查の延人員は $200 〜 250$ 人に及んだという.

大部落は岡山県北部，津山市の西北 5 里，鳥取県境から 4 里， $400 \mathrm{~m}$ 以上の早壮 年期の山地にとりまかれた，瀅谷のふところ深いところにあり，バス垂場まで自転 車で $7 \mathrm{~km}$ ，近道で山越え 1 時間余という位置にある. 戸数 47 戸，山林 275 町歩，

(全面積の $93 \%$ ），耕地 21.4 町，和牛 48 頭という部落である. 本報告はこの部落 を，第 1 章 位置と自然環境，第 2 章 近世史料の分析と明治以降の農林業生産の 発展，第 3 章 経済の構造として（a）明治以降戦後までの土地所有の特質，（b ） 山村経済の展開過程，第 4 章 社会的特質として（a）江戸時代の家族構成・相続 等の分析，（b）各種の社会集団とその意識，（c ）民俗，（d）衛生ならびに医学的 
調査，等によつて，明らかならしめんとしている.

大部落の近世村落としての主な性格は, 社会的経済的な等質性と, それとの関連 においてみられる停滞性であるという，それはたとえば庄屋の著しい交代制にあら われ（村役人系譜表，34 37 頁)，経済的にも江戸中期以後は持高 10 石以上なく， 1石以下゙ $10 \%$ 代 (幕末 $3 \%$ ) で 3 10 石に集中している (46頁の表). しかしそ れが明治 23 年では，1〜 5 町（所有） $53 \% ， 3$ 反以下 $28 \%$ となつている（54頁 の表より計算). この点，ピラミッド型の他の部落とは異なるが，すでに貧農・半 プロ層が形成されていたようにみえる.この村の部落が，北の最奥から南の谷口に 向つて, 山林原野中の部落共有地の割合がへつていること（52 頁の表）や, 耕地に ついて村外地主の攻撃を受けやすかつたこと（59 頁の図）等と比較すれば，調查部 落は農民層の分解が相対的に少なかつたということはできる.しかしそれは，戦後 において多数の帰村者を迎え，無産の㞸焼層が成立したことでやふれた。この部 落では農地改革は，経営面積には何等の変化も与えなかつた (130 頁折込付表). た だ農繁期に，小作人の地主に対する労㗢の提供（手伝い）が，軽減された小作料を 補う意味をふくんでかなり行われはじめたという.(142 頁).

現在の階層構成は表の通りである（耕地・山林は反，146 頁).Aは富農で水田 6 汉以上 (自給に 5 〜 反を要するので). 山 林 10 町歩以上 ( 1 町歩 $1 \sim 1.5$ 万円の粗収 益があるので) で年々相当の資本蓄積の可 能なもの, B は中農でほぼ収支償い, 動力農 具等も整備したもの， $\mathbf{C}$ は貧農・半プロ層 で，自己の耕地・山林だけでは家計を支え られず，余つた労働力で山林を買い，趜孷 生産を行うもの, Dは林業労㗢者で, 他人

\begin{tabular}{ccccc} 
& 戸数 & 田 & 畑 & 山林 \\
\hline A & 10 & 7.3 & 2.3 & 167.9 \\
B & 16 & 4.6 & 1.4 & 46.4 \\
C & 8 & 1.2 & 0.9 & 28.9 \\
D & 13 & 0.1 & 0.2 & $7.6^{*}$ \\
計 & 47 & $(3.4)$ & $(1.2)$ & $(58.6)$ \\
\hline
\end{tabular}

* 244 頁の表には 7.7 となつている. に雇われるか，または原木を買つて炭燒きをする。

この部落の現金収入源は，商品作物，マユ，林産物（岸，用材，コウゾ，ミッマ タ）の販売であるが，それは大体, 明治 30 年代の前半で交代した（85 頁以下， 165 頁以下). 茶, 大麻, 苧麻, 藍葉, 葉タバコ，コウゾ等の減少，桑，コンニャ ク：ミッマタ，新しい野菜類の増加が目立つ. 萎㞸は刚敷慣行の衰退によるかつて の採草地の減小 (241.頁の表) のために起きたものであり，それはまた明治時代の 癑業を支えた刚敷の運搬のための牧牛とも関係する (219 頁以下).これらの部落経 済の諸相が. 農・林・畜産の各方面から論ぜられる.

社会的特質としては, 山林の半分が 32 人持という本百姓の総有であつて（明治 23 年，52 頁)，いまなお，この入会関倸が強く残存しており，6大同族集団がかな り強く㗢いている (319 頁以下). 
付録は 1 つは全農家の家族・財産推移一覧表で，元淥 11 (1699) 年から昭和 29 年までの石高（明治以降は反別）と男女人数，牛等を 1 大表にまとめたもの，他は 家系図 10 枚で，いずれも現世帯主から8～10 代まで溯ることができる．調査部落 の実質的な内部関係を追求するときには，必要であるが，本書の記述範囲では必ら， ずしも，必要とせず，むしろこれ自身が 1 つ問題をもつ資料といえよう。

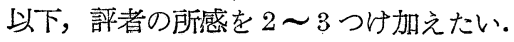

1. 経済構造の音で，土地所有について，この部落が近世以来，等質的であつた ことを数学的に示そうとしたところがある (149～151 頁). 所得や税の分布を示す ときによく使われるロレンツ曲線の不平等係数を利用したものである. 宗門改帳な ぞを資料として，“平等係数”というものを元祿から最近まで（1700～1954）曲 線で示してあるが，どのような操作をしたのかよくわからない。“附”とはしてあ， るが，この 2 頁だけが，ひどくかけ離れた記述である.

2. 部落の生活で調查すべきものは多々あろうが，氏神や葬祭のことが詳しいに かかわらず，食生活は消費の項の 1 部 (271〜275 頁) で少しふれられているにすぎ ない. 自然の生物相の末尾に，“鵎は各戸に飼われているので，大切な動物蛋白源 となつている”（18 頁）とあるが，経済の章で牛のことはあつても，䳕がどんな風， に飼われているかは書いてないし，前述の消費の項でも，民俗の章でも，それが村 民によつて動物蛋白の給源として，どのように食べられているかは全然ふれてない。 米を食うか麦を食うのか，食生活を 1 つの重要な調査項目として，とりあげないの. は正しいのであろうか.

3. 部落の総合的な調査は，もとより各方面からなさるべきであるが，教育 (355 頁以下)，民俗 (376 頁以下)，民家 (386 頁以下)，とくに医学的諸調査（396〜 429. 頁）は社会調査として，その重要性が重大であるだけに，前半との関連が重視され ねばならない，本書においては，医学班の調査は純粋医学的であつて，村民の皮膚 の色とか，背の毛流とか，あるいは頭のつむじの数，耳を動かすことができるか否 か，舌の両縁をまき上げて筒形にし得るか否か等々の調査もあるが，これが惏の. 生活とどういう関係があるのだろうか。歴史の項で，全村民の家系が数世代にわた つて，調べあげられているが，遺伝の調査としたら，てれらが役立つものかどうか. トラコーマの調查は経済的階層や生活状態と，いかに関係するかが問題であろう： 社会的医学の調査がこのような調查には必要なのではなかろうか.

4. こういう調査で，人文地理学者は何を受けもつものであろうか. 本書のなか で，地理学者はかなりの主導権をもつているょうであり，他の科学のなかにとけこ んで，調査を進めたといえるのかもしれない、しかし地理学者の執筆した “明治以 降の歴史的環境”とそのあとの農業経済学者のかいた “経済の構造”とをくらへて みると，思い半ばにすぎるものがないだろうか，後者は農業経済学の立場から，明 
治以降を分析しているにかかわらず，前者は何の立場もなく，ただ統計の解釈にす ぎない，資料の展示という意図もあろうが，ここらは潔く他の專門学者にまかすべ きではなかろうか.

そうとしたら人文地理学者は何を以て，共同調査に参加すべきか．本調查をなす にあたつて，地理学者として，このような役割と職能の問題について，検討を加え たのであろうか. 古島氏編の “山村の構造” や近藤氏編の “むらの構造” には，地 理学者が参加していないが，地理学者の参加している本調査は，どこにその特色を 見出すことができるであろうか.

私見を述べれば，このような各専門の共同調査において，地理学者の担当すべき 点は, 一つは自然環境との関連（環境論に宿らぬ限りにおいて，地域内の場所的 相違，また他地域との相違（対象地域が小さければこれのみになることもあろう） 等が問題となろう．地域的相違としては，岡山県内の他の山村，あるいは県外の山 村との比較（何も同様の調查を 2 回くりかえさねば，比較ができないことはないし， また他にもこのようなインテンシブな調査もないではない)，あるいはすでに行わ れた岡山県内の農村，漁村との対比などに，地理学者の独壇場があるのではなかろ ろか。

前にも述べたように，行政村富村はかなり山奥と谷口近くではちがうからここ いうところから，地理学者の分析の手が加わるのではなかろうか（統計資料の関 係で，部落別にみられない場合には，それだけでは不明確である。本書にもその不 便が多少あつた。これは今後市町村合併で，統計資料の利用上，地理学者には困つ たことである.）

しかし幾多の問題があるにせよ，このような多数の專門家の協働によるモノグラ フが，単に中国地方の 1 山村の事実としてのみみられずに，学界の共同財として， 日本の1面として読まれるならば，学界に寄与するところが大きいと信ずる.

石田龍次郎

\section{高橋浩一郎編：日本の気象 （毎日ライブラリー）}

毎日新聞社， B 6 判， 288 頁，1956 年

毎日，天気がわれわれの話題になるこの日本では，本書のような刊行物は，大き な意義を持つものである.とくに毎日ライブラリ一の性格からいつて，読者は広い 一般市民であつて，年令的にも職業的にも，かなりの幅が想像される。このような 人澾を対象として, 進歩の歩調が，部門によつてきわめて乱れている日本の気象学 の現状で，いわゆる教養書を編集することは，それ自体が難事業に属する。また； それだからこそ，日本の気像が説かれる重要性があるのだが，日本では，北から南 
まで，あるいは海岸から高山の頂まで，さまざまの気象気候を経験する・だから， ここに住むすべての読者に，それでれ自分の体験に関連させて，日本の気象と題す る 1 冊の畫物で，それを理解させることは，これまた困難の多いことであろう。こ れまで，気象学の教科書はよいものがいくつかあつたが，日本の気象に関する教養 書で，まとまつたものがなかつたのは，おそらく，以上のような理由と思われる.

本書は，高橋浩一郎氏のほか，小出博・関口武・根本順吉の諸氏が加つて企画し， 討論編集の結果できあがつたもので，上記の難題はみごとに突破されている．内容 は大別して，全般的な気候と，春夏秋冬の四季別の説明である. 詳しくは19 章に わかれ，各章を分担執筆している.（1）日本の気候と生活, 関口武.（2）気候は 変化しつつある，高橋浩一郎.（3）春の風，三谷一郎.（4）梅雨，須田健.（5） 豊年と凶年，坪井八十二・川田信一郎.（6）農業と気象，同上. (7) 夏の暑さと 雷雨, 神山恵三. (8) 人工降雨, 磯野謙治.（9）台風, 高橋浩一郎・久米庸孝.

(10) 豪雨, 渡辺和夫. (11) 大雨と洪水とダム, 小出愽. (12) 秋の空, 根本順吉. （13）世界一の雪国，四手井綱英（14）雪崩，小出博.（15）霜柱と凍上，花島政 人. (16) 航空とジェット気流，毛利圭太郎. (17) 都市の気候，関口武. (18) 死 の灰の行くえ，三宅泰雄. (19) あすの天気，根本順吉. 以上の通りで，最近の主 要な問題までよく集めている，また，分担執筆書にありがちな，畫き方の粗密や難 易などの違いは，あとがきに述べられているが，十分，手が加えられただけあつて， あまり目につかない.

つぎに筆者の読後感と批評を少し加えたい。まず，本書は「日本の気象」という 表題であるし，内容を読んでみても，日本の「気象」の解説書であると思う．とこ ろが，編集後記に属する高橋浩一郎氏のあとがきには，「本書では日本の気象と生 活との関連を書くことに重点をおき…‥」とある.編者が，もしこの点をねらわれ たのなら，論評はまた別の観点から行わなくてはならない.しかし，あとがきにこ だわる必要むないと思うので，本書に示されている内容そのままを受取ることにし たい、評者ばかりでなく，多くの読者も同じく，生活に直接関係のある気象の説眀 を読みとり，また，それを期待するのではなかろらか、つまり，最近の気象学の進 歩のなかで，身近かなことの知識を得たいのである。これに答える部分としては， 気候変化の問題, 梅雨の原因, 人工降雨, 台風と被害, 大雨と洪水, ジェットスト リーム，放射能雨，数值予報などがあり，充分述べられている.こういう問題は， 現在，ジァーナリズムのホットニューズであるばかりでなく，気象学の当面する重 要な問題でもあり，本書においても読みごたえがある.つぎには，とくにホットニ ニーズではないが，日常よく気になつたり，目にとまつたりしている疑問に答える 部分として，春の暴風と大火，雷雨，秋の澄んだ空，積雪と降雪の性状，雪崩，霜 柱，都市霧，都心の気候，天気予報のあたる度合，などがある.このうち天気予報 
の 1 文は有益であり面白い. 以上は，いずれも身辺に直接関係ある気象の解説であ る.このほかに残るのが，いわゆる生活との関連を記述した部分である.すなわち， 気候と衣服・住居などの生活様式との関係，豊作と凶作，農業と気象，スキーその 他雪と生活などである. 問題なのは，このグループのテーマであり内容である.

評者の希望をいうと，問題が多いこういう気象と生活との「関連」を強調したテ 一マについては，別に1書としてまとめ，本書には，気象それ自体の閣題をもう少 し多く，かつ詳しく述へてもらいたかつた．例えば，生活との関連というと，水産 業や工業の立地と気象との関係，ビルディングや木造家屋内外の気像環境比較など， 現在の日本において重要な問題が多い。もちろん，本書は教科書でないから，あら ゆる問題を，同じウエイトで論述する必要はなかろう．しかし，一方，気象自体の 問題で，解説されてょいものも少くない，例えば，空中電気，日射や輻射，大気活 染，電波気象，山岳気象などである，それに，てききれは学校における気象教育— いわゆる観測技術でなく，観測計画・資料整理・利用・考え方など——もつけ加え られるとよかつた。

元来，人間生活における気象など自然現象の利用・制約，あるいはその効果など を示すことは，その過程が簡単でない場合は，非常に問題がむずかしい.「徐を持 つている」ことは，確かに生活との関連の1つであるが，「温帯地方における文明 の発達」までも，これと同じ調子で論じさることは，多くの誤解をまねく、いいか えれば，長期間にわたる関連，広範囲の地域についての関連の仕方を論じる場合な ど，その議論には，多くの立場がありうるはずである．つまり史観がなければ，読 者になつとくのゆく説明は示されない，本書にも，気候と国民性・文明などとの関 係の見方の例として，和辻哲郎（14頁)，藤原咲平 (14〜15 頁)，ハンチントン

（26〜33 頁）の紹介がある. しかし，いずれも無条件に賛意は示されてないにか かわらず，埶筆者の，はつきりした意見も示されてない.したがつて，例えば， 「凉しいということを利用して，いくら立派なハクサイやキャべツが畑にできたと しても (中略)，気象を経済的に有利に利用するには，それ相当の資本の投下が行 われなければならない.」(81 頁) とあり，あるいは，「防災対策の基底には経済問 題が大きく横たわつており，経済をはなれた防災対策はありえない.」(128１29 頁）とあつて，かなり現実的な問題が提起されているにもかかわらず，具体的にど ろなのか，また，読者はどう考えればよいのか眀らかでない. 以上のほか，1〜2 語句の誤りではないかと思われる点があるが，全体に関連するほどのことではない。

筆者の感じたのは，以上の通りである．本書のような教養書が，今後ますますこ の国で普友することを望んでやまない. 


\section{シャノン・マッキューン: 朝鮮の遺産 \\ Shannon McCune : Korea's Heritage;}

\section{A Regional and Social Geography.}

Rutland, Vermontand and Tokyo, 1956. \$5.00, (極東 \$3.50) 250 頁, 地図 21 , 写真 95 葉 (64 真)

これは世の常の地理書ではない，数奇を極める半島と人々に，イデオロギーを超 えた隣人愛を以てその過去，現在を述へ，更に未来に期待し，世に訴える愛国の書 とも言うべきものである．そのため，足と豊䈏な資料で蓄積した結果は，多くの人 達を対象とし，極めて理解し易い文体で，読者をして生れ故鄉に対する親近感と， generosity に満ちた 1 米人著者の，床しい人柄を充分感得させよう．多くの写真に 現れた民衆の笑顔は，日本人にとつて驚きであり，ここに本書の真実性がある.

I．遺産の概観. 他国干捗を生む極東の心臟部と，大勢力間の橋の位置，各地の 特殊性では山地と低地，南と北，東西の気候，都市と田舎，産業構造，人口分布等 の相違の大観は，全巻を通ずる全地域相寄つて1つの朝鮮となるべきことを強調す る序章. II. 自然条件. 学位論文が朝鮮の気候区だけに夏に始まる月別の気候変化 と農民生活は鮮かであるが，地形の解釈も深い含蓄を見せ，年季の強さを見せる. “平穏の一刻，緩かな丘を攀ぢ，古い塚のほとりに腰を下し，木ふに蔽われた山及 を眺めやれぱ，そこに悠入とひそやかな美に打たれる”態度で，自然を観ているが； 人と同様，疲れ切つた土壤を，多様な地質と対照することを忘れない．歴史は 秀れた業樍を遺した朝鮮史家の亡兄のものの引用に始まり，悲惨な外国支配を述べ ているが，特に海賊の hit-and-run 戦法に始まり，拭切れ奴憎悪となつた日本の 植民史は，謙虚に読むべきであろう，IV. 政治構造では史的裹付けにより，中国の 懦教精神の導入と庶民生活と王朝政治，日本による警察国家，根強い非協力の抵抗 と村落構造等が中心で, “Koreans should be taught to follow, not to know," は德夢を想起させる.しかし $38^{\circ}$ 線ほど無意味かつ惨酷なものはなく，遂に運命的 な位置が生命を奪う分断となり，最大の破局に宿れたと．V．人口分布では山地と 低地，都市と農村，南と北等による不均衡が中心となり，貴重な資料で変遷に及ぶ. 日本支配以後の人口上昇と産業の地域的相違は興味があり, 国内外の移動を歴史的 かつ地域的に見ているのは，注目に価する. VI. 朝鮮人とその生活は言語, 衣服, 髮形，食事，宗教（夫婦の信仰の相違，自然崇拝や墓地の選定等)，遊贱に至るま で，著者の理解の度を最もよく示す章で，特に家族制度，部落構造に抢ける古い懦 教精神，家系，門閥等，内側からする保守的遣制の解剖は，長い伝導と研究に終始 した McCune 1家にして，始めて可能であろう．彼等を単純，怠忨で顽が必要だ と見た日本人と異り，“the Irish in the East”として，その生活力の旺盛さと誠 
実さを高く評価. 住居や集落生活についての, 古いものと新しいものとの交錯の着 眼乡見逃せ如。

VII. 基礎産業で水田耕作を中心とする農業とそれに結付く漁業と林業. 特に米を 商品化した日本濃政の功罪を衝く，日本の為の食糧給源とし安全辨とし，時には年 産の $\frac{1}{2}$ を持去つて地主層を没落せしめ小作民を增加した反面，灌渴，開拓，品種 の改良，管理の改善等の努力を高く評価し，朝鮮の近代化への寄与も亦認める. 低 地の水田, 丘陵地の畑作の定着農民と，特に北部山地に多い火田民との生活の対比。 移動農民の定着へのプロセス等は，単なる好奇心からの oriental culture 分析で はない，世界 6 位を占める漁業についても，日本の努力を認め，イワシの急減と沿 海生活の変化や，陸との結付きにも考慮を払つている. 森林では山火事，乱伐（農 民の燃料；火田民，日本の戦争造船の罪）に上る土壤侵蝕や，二次生林や森林夕1 プ等. VIIは前章に対し, 新しい工業について日本治政下の発展. 北部（地域別の所 で詳細）の鉱山，電源及び重・化学工業や鉄道，道路，港湾建設，精米業について. 戦争との結合は当然の京ながら，古い家内工業或は農家の副業と工業化との関係は, 説き得て妙. 鉄道建設を日本最大の投資として，急速な鉄道網完成を，地域の特徵 と結付けて詳述. 知らされなかつたのは, 朝鮮人のみではない.しかし戦後の日本 人技術者の退去と動乱は，南北共に適確無惨に破壊し,更に $38^{\circ}$ で不随化した。（写 真に歷然).

VII とVIIで，南北の有無を通ずべき必要不可欠を切言し，“もつと光を”との南の 声を伝える. IXとXは北と南の地誌で，地形，気候，土地利用，人口密度，行政区 と歴史等から，北を 3 ，南を 7 に再区分する. 南北の気質の相違や経斎生活の差は

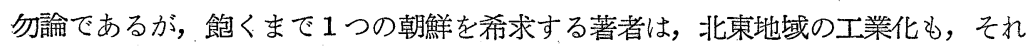
は土を離机得奴人々の上に，1夜にして被せだ゙ニアであり，二重生活で本来の必 のではなく，ただ日本を米・ソに置換えただけでは救われねと．南では人口移動が 興味深く, 中南山地では小藤説への反論も. 南西の米倉庫と古い両班との対照や， 済州島の沿海生活等巍陵島まで，地名（亡兄と共に著者も地名研究の一権威）に苦 しめられるが，かつての贔罪と将来の友好への寛大ささえ持てば，楽に読続け，XI 結論に入る.ここで再び位置と地域的特性の遺産を振返り，2 分された不自然を強 く操返す．動乱は物的な破壊より，南北それぞれに与えた崩れた憎悪が大きい，し 汃支柱である農民は，かつてない苦しい生活と人口圧に喘ぎつつ働く. 工業も亦， 一度達成されたものを，自らの手で再建し得るであろう．苦難の道は遠くとも，統 一朝鮮の彼岸の見える限り. 混乱の中にあつても“人的資源こそ最大のもの. 無論, 欠点も人間だからある.しかし力，過去幾多の鎯難を淩いで今日まで永らえて来た この力がある. 朝鮮の未来は，バラ色でのみ描かれないし荆の道の遠いことも確か だ・しかし,今ほど,かつて示した強勒さの要請される時はない.問題を惹起した遺 
産そのものは，彼等にチャンスを用意し，彼等亦その重要性を知り尽している。朝 鮮をして，正しくあるべき位置を占めさせようと，手を差伸べる人達の全部は，こ れを知るべきだと結んでいる。

本文外の付録は，精選された 95 葉の写真（写真のみで独立した価值を持つほど， 立派なもので，あくの掖けた詳細な説明が付けてある）の外，書評的な多くの文献。 地名研究，人口その他新らしい統計資料が，そういう事を知りたい人々を満足させ よう. 離れて見て初めて判る想である．朝鮮はまことによき代弁者を得た．偏見が 出るかも知れ妨と断つてはあるが，人類愛—出しやばりの嫌いな著者の苦笑が見 えるが——とも言うべき，広い心もて弱い人々を愛し，貧しさの裡に美を見出す稀 な異邦人に，感動せぬ者はあるまい。自由に思う所を歩ける環境を羡みつつも，歩 いてこそ知る土地と人とのありようを，理解し易く書いた才能と努力に敬意を表し， 併せてこの1書を出すまで，この地の研究と教化に捧げた父，兄をはじめ，今は Provost として忙しい傍に内助の功を尽す最愛の夫人に祝福を送ろう. 著者がフル ブライト教授として来日し数々の寄与をされたことは断るまでもあるまい.

山岡 政喜

\section{キンブルおよびグッド編集 : 北方地域の地理}

\section{G. Kimble \& D. Good : Geography of the Northlands.}

American Geographical Society Special Publication No. 32

New York, 1955. 534 頁, 図 47, 写真 75, 付録地図 1.

本書は今後の世界において，ますます重要な位置を占めると思われるユーラジア， 北米の北方地域について Kimble（熱帯アフリカ研究所長）とGood（経済学者） とが責任編集者となり，おもにカナダおよび米国の大学や研究所の学者あるいは北 方地域の専門家に委嘱して分担執筆させた，はじめての大規模な，綜合的地理書で ある.この部分の地理的理解については，従来の業績はまだ断片的なものにすぎな かつたが, “いやしくも人閒の主要な要求の 1 つが，世界を理解する事にあるならば， 地表のどの部分でも，軽視されてはならない”（序文）という考えの下に，陸地の 1/5を占め，しかもそれに続く南方地域に重要な関係をむつこの北方地域の，地理的， 綜合的な把握をめざした野心的な著作である.

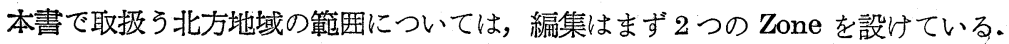
1つは北極地方 (Arctic region) であり，他はそれにつづいて拡がる亜北極地方 ((Sub-arctic region) である.しかむこの Zone の設定に当つては，たとえば前者 については，従来の $66^{\circ} 30^{\prime} \mathrm{N}$ を以てする機械的な北極圏に満足せず，これに代え 
るに 7 月の気温が $50^{\circ} \mathrm{F}$ の等温線を以てし, 後者については 1 年のらち 4 カ月の平 均気温が $50^{\circ} \mathrm{F}$ をこえない地域を以てした。したがつて北方地域とは，ここに挿入 の図版に示すごとき複雑な境界線をもつこととなつた。

かくして，定められた北方地域について本書はまつこれを 2 部に大なく分ける. 序論 (D. Good)につづく第1は“系統的研究” の部であり，ここでは（1）地形 (J. R. Mackay. British Columbia 大学地理学助教授)，（2）水塊，その移動，氷 の被覆 (M. Dunbar. Mc Gill 大学動物学助教授)，（3）気候と気象 (F. Hare. Mc Gill 大学地理学教授),（4）陸地扰よび内陸水の生物地理 (P. Dansereau. Michigan 大学植物学助教授)，（5）海洋の生物 (M. Dunbar. 前揭)，（6）土 着人口 (J. Teal. 北方農業研究所の人類学者)，（7）移住人口（同上)，（8）交通 (P. Baird. Aberdeen 大学地理学研究所員)，（9）北方地域の富-I. 鉱物資源 以外の天然資源（S. Haden-Guest. “世界森林地理誌” の編集者)，(10）北方地域 の富一II. 鉱物資源 (D. Good. 前掲)，（11）北方地域の富一III. 経済的発展 (D. Good および Haden-Guest. 前掲)，（12）政治的および戦略的状況 (D. Good お よび Haden-Guest) の各章より成る.つついて第 2 は“地域的研究” の部門で， （1）アラスカ (J. Teal. 前掲, および I. Skarland. アラスカ大学人類学教授), （2）北西カナダ (D. Good)，（3）東カナダ (J. Bird. Mc Gill 大学地理学助教 授)，(4) カナダ北極洋群島 (P. Baird. 前揭)，（5）グリーンランド (P. Uren. カナダ国防研究所員)，（6）アイスランド (J. Bird. 前掲)，（7）スヴァルバード およびャン・マイエン島 (S. Orvig. Mc Gill 大学地理学講師)，(8)ソ連一ヨーロ ッパ北部地方 (B. Zaborski. Mc Gill 大学地理学助教授)，(9) ソ連一西シベリヤ (同上)，(10）ソ連一中央シベリヤ（同上)，(11）ソ連一東シベリヤ (同上)，(12) カムチャッカ，コマンドルスキー諸島および千島（同上），(13）ソ連一北極洋諸島 （同上）の各㔬にわかれる，そして最後に結論（D. Good）があり，かくてほとん どあらゆる項目，地域を網羅して余す処がない.

全部にわたる詳細な紹介は，紙数の関係上到底不可能なので，重要なるののみを いくつか拾つてみよう．第1部で特に興味を感じるのは，自然的方面としては“陸 地および内陸水の生物地理”の章であり，高度の環境的圧力に適応する北方地域の 生物がエコロジカルに記述される．ここで植物被覆を北方から順にツンドラ，タイ ガ，北方森林 (boreal forest) および落葉林の 4 つに分ち，“Taiga は小さな集団 または間隔のひらいた樹木，背の低い灌木，多種の草や夥しい蕉苔類をもつ地域” であり, “Boreal forest は背の高い針葉常緑樹が連続する地域である”としてい るのは，従来のTaiga すなわち針葉樹の大森林と理解していた評者にとつて，大い に反省させられるむのがあつたまたここに示されたいくつかのエコロジカルな図 解（たとえば北極圏湿地带の季節による植物の变化，ローレンシャ楯状地における 


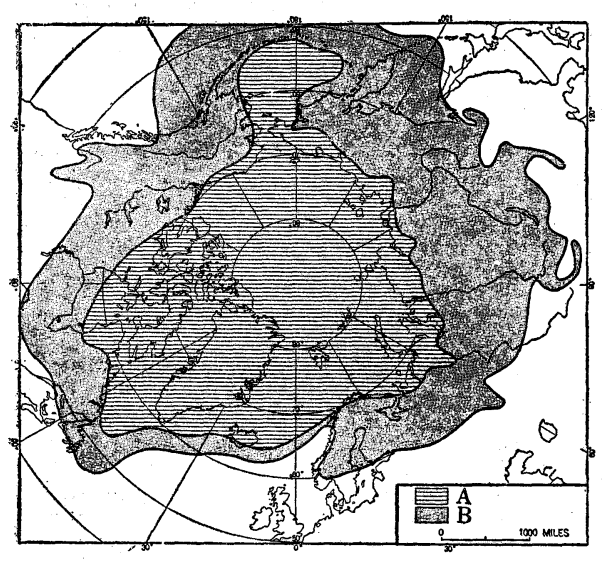

本書で取报つた北方地域の範囲
A 北極地方
B 亜北極地方

泥㞸地形成の段階を示すむのな

ど) は，貴重な資料であろう。

さらに人文的方面で注目される のは，“土着人口”の章である. 特に北極をめぐる地域の文化的パ ターンの研究が面白い. 著者はこ こで，“寒気に対する保護とそれ からの逃避”をテーマとして，こ の地域の衣食住と環境との関係加 ら，文化的パターンを理解しよう と試みた。たとえば人間が多雪地 帯を歩きまわる道具としての雪沓 をとりあげて，チェクチやラップ 人の使う，原始的な子のから，最 高の段階であるスキー（すでに BC. 2000 ごろスカンジナビヤて 使われている）に至るまで，その発展過程や地域的分布を調べている。ここにさし 絵があつたら一層効果的であつたろう。

“移住人口”の章も重要であり，ここでは接続する南方地域から移住してきたも のを，動機によつて6つに区別している.すなわち（1）民族的移動時代に圆険者 稙民者として，新らしい土地を求めてきたもの（Viking など），(2）軍隊の一員 または政治犯として来り，その後定住したもの，(17 世紀頃のカナダの英，仏軍の 兵士，シベリヤの住民など)，（3）天然資源の開発に来て定住したもの（ロシヤの 毛皮商，アラスカの採鉱者など)，(4) 経済的に南方地域からあふれ出し，定住者 として北方にチャンスを求めてきたもの（1930 年代のアメリカの不況をのがれて アラスカに定住した集団など)，（5）北方での居住は一時的であるが，そこの恒久 的企業または集落と関係のあるもの（スピッツベルゲンの炭坑夫，現在の米ソ両国 の基地に勤める人々など)，(6) 国家的，政治的単位による北方への拡大の前衛を なすもの（アラスカ開発に伴う米人など）であり.これらの各々について，その構 成民族や生活様式を詳細に述へている.

さらに移住民と原住民の接触の問題におよび，初期にはかなりの反目もあつたが， 今は両者の文化が互に接近しつつあることを指摘する．それは環境適応の上から新 来のものは防寒に対し，在来のものの生活様式を模倣せざるをえず，また原住民は 夏の生活様式で新来のもののそれを採用せざるをえなかつた事が，大きな理由の 1 つだとしている. 
“経済的発展” の章にも新らしいデータがもられている.ここに扱つた地域の全 人口は，3693.5 万(1950 年) であり，そのうち北極地方に住むものは，38.9 万に すぎない. 亜北極地方ではいくつかの人口密集地ができている．また全般的に北方 では最近人口が徐々に増加しており，ことに北米の部分の增加は，移住者数の増大 によることをのべている.

次に第 2 部の “地誌的研究” の章で，特に評者が興味をもつたのは，北極洋に浮: ぶ島々の記述である.たとえば“カナダ北極洋群島”では，ここが島の数では東イ ンド群島に次ぐものであり，その中には世界の島で上位を占める大島もいくつか含 まれるが，同時に考古学的遺跡も多いことを知らされる．著者はこれを．Thule 文 化と Dorset 文化の 2 系統にわけて抢り，この遺跡は過去のこの地域の気候変化と む結びつくらしい.たとえば Repulse 湾南部で発見される Thule 文化は, 当時氷 が少なく，大きな海の晡乳類の生存に適した環境と結びつくという. 現在のこの群 臭の人口は約 3000 のエスキモー，約 300 のヨーロッパ人であるが，前者の $2 / 3$ と後 者の $1 / 2$ は Buffinland と Somerset の 2 島に集中していることがあげられ，また すべての集落や恒久性ある土民の Camp は，いずれも食料蒦得と結合して，海岸 に位置していることが注目される.368〜369 頁にある群島の集落一覧表は，貴重 なデータである.さらにこの群島が，北方地域の科学的研究（自然および人文両方 面の）の豊かな処女地であることも興味ふかい．評者はこうしたいろいろな点で，

東インド群島との比較研究をしてみたい意欲にかられた.

いずれにしても，この北極洋群島をはじめ，グリーンランド，アイスランド，ス ヴァルバード，ヤン・マイエンなどの記述は，従来多くの地理学的文献の乏しいと ころだけに，ここに盛られたデータは，われわれに寄与するところが大きい.アイ スランドでも首都のレィキャヴィクだけに，近年全島人口の $40 \%$ が集中したこと や，過去にしばしば気候寒冷化のため，農牧が不能に陥つた䇟害の多かつたことな どは，耳新らしい事実であつた。しかしこれに反し，ソ連の部分の記述はやや Conventional で，物足りない感じがある.

要するに本書は気候要素によつて，大胆な地域区分を行い，従来のものにくらべ ていわば “横割りにした地誌”であり，その試みでは成功しているものと思われる。 それはこの北方地域が自然的にも人文的にも，1つの Uniformityをもつた地域た からである.な沶巻末に（1）紀元前の Pytheas 以来現代までの北方地域の著名 な地理的探検の年表，（2）北方地域の動植物の学名と普通名の対照表などをのせ ているのは，親切なやり方である. 全部アート紙印刷なので多数の写真も鮮明でよ い.

別技 篤彦 


\title{
フーヴァー：経済活動の立地
}

\section{E. M. Hoover : The Location of Economic Activity}

\author{
New York, 1948, XV および 310 頁.
}

1. 本書は合衆国に扮ける立地問題の研究者として，ユニークな存在をもつフー ヴァーが，この問題に体系的な考察を加えることを目的として書かれたものである が，著者の主要な関心は，資源や産業の現実的分布の記述にあるのではなく，それ らの“相互関係を支配する原理を明確に論述する”（1頁）点におかれている．内 容は序論と 4 篇 18 章によつて構成されている. 序論では立地の基礎的問題と本書 の構成が述べられているが，つぎの点が強調される．すなわち，今日漠然と論ぜら れている諸問題の不明瞭な点は，その基礎を立地論的考察に求めなければならない. しかし，このことは経済地理学がこれまで示してきた資源や人口等の地理的条件に よつて示されうるものではなく，かりに地理的条件が均一であるとしても，異つた 立地の配列は考えられるのであり，立地問題の基楚は経済の内面におかれなければ ならない.

第 1 編「立地の選択と分布」は本書の中枢をなす部分であるが，立地決定の 2 大 因子として，輸送費と生産費がとりあげられ，さらに労働費と土地費が前 2 者との 関連において吟味される。

第 2 篇「立地の变化と適応」は，第 1 篇が立地の静的均衡をとりあつかつたのに 対して，動的な観察である.ここではまず，立地変化の原動的原因を指摘した後， 立地移動の意義，その相互的関連，合衆国における立地変化の一般的傾向が述べら れる.つづく章では技術と立地変化の関係がとりあげられ，“技術の改良は輸送費， 動力費, 労働と原料の必要量等の変化を通して立地の分布に影響をおよぼしてきた”

(184 頁）ことを明かにする.この篇の最終章では，変化に対する適応の問題が， 経済的発展におくれた《後進地域》，資源枯晹によつて産業を失つた《擱坐地域》， 田園化の過程によつて影響をうける都市の《调萎地域》, の 3 つの範疇において述 ベられる.

第 3 篇「境界の立地的意義」では，立地に影響をおよぼす政治的境界の意義が B. Ohlin と A. Lösch にもとずいて述べられ, つづいて, 立地政策の目的と方法 が最後の篇で試みられる，以下，第 1 篇についてやや詳細な紹介を試みよう*.

2.まず初章では，立地に直接重要な関係をむつ輸送費の構造が分折され，この 輸送費にもとずく産業立地が，つづく章でとりあげられる、いかなる生産も原料を

* 本書はすでに，他の機会に紹介をしたことがあるが，編集委員会の好意的すす めにより，視点をかえてここに再度の紹介を試みた。 
工場にもたらすための《取得費》と，製品を市場にもたらす《提供蕒》を必要とす るが，両費用の節約は立地的に異つた方向へ作用する．かくて立地は，用いられる 原料と製品の関係，生産段階によつて，原初的には原料と市場を結ふ線上において、 比較利益の調和をはかる. 線上の点として考察された立地は，次章において地域的 考察に移され，生産を中心として《需要地域》と《供給地域》が描かれる. 運貨の 構成が等しい輸送機関を利用する場合は，需要地域は距離によつて決定され，境界 の明確な地域が構成されるであろう。だが，実際には事情が全く異り，輸送上の競 争，特殊な輸送路等によつて，需要地域は，あるいは拡大し，あるいは縮少して， その境界は錯綜し，さらに重複する.《長距離輸送経済》や《運賃吸収》はこの傾 向をさらに助長する (第 4 章).

生産費のもつ立地的意義は第 5 章で考察される. 生産費が地理的に異る基礎は生 産要因の移動と分割が，自然的・社会的制約の下に十分におこなわれ得ないという ことにあるが，このために企業は生産要因を高度に利用し得る立地を求め，異つた 位置では，生産要因の組合せに異つた比率を与えなければならない。他方，生産費

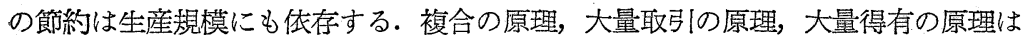
立地と関連して生産を太規模化に導く傾向をもつ.

土地はその拡延性と不可動性という，2つの本来的な性質によつて，つねに《位 置》への考察を余儀なくせしめる. 異る位置は異る地代と地価をもたらすが，それ は2つの面においてあらわれる１は輸送費に影響を及妓すものとして考察される 位置であり，他は生産費の増減に関係して考えられる位置である. 後者はその位置 のもつ物理的・化学的性質に由来し，特殊な産業には重要な関係をもつものではあ るが，より重要な一般的考察は，前者に向けられる. 競争の存在するかぎり，好位 置の洒格は騰貴するから，それに耐えうる位置利益の利用によつて，すなわち単位 面積当り最高の地代を支払いうる利用によつてのみ，その土地は意義をもつ. かく て問題は《最高地代》の決定に向けられるが，それは輸送費の水準と構造に依存し てカーヴを描く (第 6 章).

土地に比べて労働は移動と増加が可能であり，その供給は賃銀率に依存し，具体 的には生活と雇傏の安全性, 労衝条件と生活条件の一致等の問題を伴う.したがつ て，労働供給の点から考らえれる立地は，賃銀・生活費の相違をもたらす具体的条 件の分析を通じてえられる (第7章). 以上の要因について呤味した後, 著者はそ れらの相互的関連と社会の外的・内的構造によつて，変形してあらわれる立地現象 の分析をもつて第 1 篇を結んでいる.

3. 本書はなによりもまず，合衆国における立地論の体系的に構成された書とし て, 同じ著者による Location Theory and the Shoe and Leather Industry と ともに，われわれの関心をそそる.しかし，おそらくは，本畫が專門家のための研 
究書としてではなく，立地問題への一般的大門書として書かれたということに，そ の理由の一端を求めることができるであろうが，われわれは本書に対して高度の理 論を期待することはできず，内容は初歩的な理論の解明と，具体的説明に終始して いる. この点，Hoover の前著を知るものにとつては，いささか期待はずれの感を いだかしめるであろう。だが，かかる本書の性格は他面において，読者を容易に立 地問題に接近させるとともに，現実的諸問題の理解に，直接有効な武器を与えてく れる.たとえば，A. Weber が原料指数の劃一的な適用によつて犯した純粋原料 使用による指向の誤謬は，Hoover の輸送費構造の具体的分析によつて，正しく修 正しうる. かくて，本書は完成された理論の提供でないということを念頭におき， その体系と分析に対するいくつかの不満を看過するなら，立地問題の入門書として， 一読に値するものである.これまで，地理学においてなした立地論への関心は，主 として形態に向けられ，その理論は“地理的取扱いと異る”ものとして省みられる ことが少かつた，その結果が，多くの場合，理論の誤用と，早急な結論として現わ れたことは，否定できない事実である. Thünen やWeber あるいは Lösch の抽 象化に不満を覚えた人でも，本書に対してはいくぶんなりとも親しみを感じ，立地 の規制に意義をもつ経済的内面の問題を理解しうるであろう.

村田喜代治

\section{マンゲルスドルフおよびリーヴス :}

\section{トウモロコシおよびその近親種の起源}

\section{P. C. Mangelsdorf \& R. G. Reeves : The Origin of Indian Corn and its Relatives}

Texas Agricultural Experiment Station Bull. No. 574 1939, 308 頁

トウモロコシの起源を明かにするためには，前世紀から今世紀への転換期以来， 多くの農学者や植物学者によつて，真摰な努力が重㸚られて来た，その間に次々と 新らしい学説が発表され，しばしば激しい論争も交されたが，この問題は今日また 解渗を見るに至つていない.しかもプレコロンビア期の新大陸において，唯一の穀 種作物であつたトウモロコシは，またアメリカの古い高度な文化や文明の成立にと つて，不可欠の経済的基盤であつたことが，認められるようになつたので，その起 源如何は，ひとり自然科学上の問題だけでなく，人文科学に関係する学者の間にも， 深い関心がもたれるようになつた，著者はハーヴァード大学植物博物館につとめ， トウモロコシ研究の権威として聞え，その起源論は最も力強い学説といわれている. 彼は従来用いられた植物学的, 農学的, 古生物学的, 考古学的, 歴史学的, 地理学 的, 言語学的諸方法に, 細胞遺伝学的方法を加えて研究を進め, その成果を基礎と 
して，堅実な推論を立てている．本書の内容は次に揭げたように，専門的論究のほ かに，アメリカの古い農業や文化との関係にも及んでいるので，われわれにも興味 が多い.

目次，1. 序説 2. トウモロコシの植物学的近親関係 3. トウモロコシの起源 に関する従来の証拠 4 . 従来の学説 5 . 細胞遺伝学的研究よりする新らしい証拠 6. Teosinte の起源 7. トウモロコシの起源 8. Tripsacum の起源 9. アメり カトウモロコシ亜科の系統発生理論 10. アメリカトウモロコシ亜科と，モロコシ 亜科との関係 11. トウモロコシの文化及び文明に対する関係 12. 結論 13. 引! 用文献.

マンゲルスドルフの学説は，その要点をとれば，三部構成の仮説といえよう．第 一に，彼はトウモロコシの起源を，南米の熱帯低地（おそらくボリヴィア，パラグ アイ，ブラジル三国の境界附近）に土着する野生の pod corn（有稃トウモロコシ） にあつたと推定する．そしてこれがアンデス東斜面（ボリヴィア及びペルー）の河 谷で，栽培されている間に，naked corn（裸出トウモロコシ）への変異を起し， さらに隔離的な谷間の環境によつて，多様型を生じたという.かくしてアンデス高 地は，栽培トウモロコシの第一次的センターとなつたと考えるのである. 第二に， アメリカトウモロコシ，亜科に属するZea Mays L. (トウモロコシ) と Euchlena (ユークレナ) と Tripsacum（トリプサカム）との関係については，次の見解を もつ.すなわち，トウモロコシとトリプサカムとは，末知の遠い共通祖先から分れ て平行的に別々に進化したもので，のちに南米の栽剖トウモロコシのうちで flint corn（硬粒トウモロコシ）が中米に伝えられ，グァテマラ高地に多く野生していた トリプサカムと雑種をつくつたのが，ユークレナ（通称 teosinte）であるとする. 第三に，このテオシントがそこでまたトウモロコシと雑交して，多様な新型のトウ モロコシを生じたもので，中米や北米に現存するトウセロコシの大部分は，これら の新型のものであると説く.したがつて，かような雑交の盛んに行われたグァテマ ラ高地は，栽培トウモロコシの第二次的中心地と見なすべきだというのである.

かく彼の学説では，N. J. Vavilof を始め多くの学者が，中米起源説をとるのと は反対に，テオシントはトウモロコシの起源には，本来は無関係であるとし，南米 起源説を強く主張している.そして染色体のコブ (knobs) の調査を始め，多くの 專門的証拠の上に，沉科学的研究による種々の証拠を綜合的に提出しているのであ る. その後, オレゴン大学の A. F. Whiting がこれまでの諸起源論に対する評価 を発表し (The Origin of Corn. Amer. Anthr. 46，1944)，10 ケ所の候補起源 地に対する評価を 10 割とする中で，彼の推す南米低地には 2 割の蓋然性しか，ふ りあてられないと批評した。これに対して，彼は抽象的な批判は解決促進に意義の 少ないことを指摘し，末刊の資料をも出して，憤然と強い反駁を加えている（The 
Origin of Maize. Amer. Anthr. 47,1945)。 また 1947 年に発表した論説 (The Origin and Evolution of Maize) (は本書刊行以後の研究を追補した好著である. 彼はアメリカの始原的農業としては，E.J. Payne，の流を汲んで，根菜栽培を主 とする熱带農業を認めている. そしてその中で作物複合の相違によつて，南米型の むのと，ユカタン型のものとを区別しているが，これは C.O. Sauer のカリブ海沿 岸一元説と比較して，なお検討の必要があろう。またこの熱带農業の伝播の上に， ペルー高原とグァテマラ高原との両地で，トウモロコシを主作とする穀種中心の農 業が，それぞれ平行的に発達したというのであるが，その際，南米の溨培トウモロ コシなどが中米へ導入されることが，前提となるわけである. 彼はこの導入の時期 を比較的新らしいものと見，これによつて，もたらされた食糧の急激な増産を，、 ヤ文明の躍進的形成と結びつけているが，この説明は甚だしく疑わしい.むしろト ウモロコシの栽培の開始は，開花期文明の前段階であるところの，形成期文化の発 展と連関させるのが，妥当であると考えられるから，かりに雑種の新型トウモロコ シの発生や伝播は，おそいとしても，flint corn の中米への導入は，かなり早い時 期にあてるべきではなかろうか.ともかくトウモロゴシ栽培の絶対年代が，今日ま だ明かにされないのは遺憾である.しかし最近，米国西南部で 5000 年前のトウモ ロコシの化石が，発見されたというニュースを聞くから，この事実の研究によつて， 年代泆定の問題にも光明が投げ与えられれば幸と思う.

宮川 善造

\section{ダグラス・ジョンスン:カロライナ・ベイの成因}

\section{Douglas W. Johnson : The Origin of Carolina Bays.}

Columbia Geomorphic Studies, No.4, Columbia University Press.

New York, 1942, 42 図 341 頁

20 世紀前半の地理学界で, 最も地形学者らしい学者ダグラス・ジョンスンが， 吃血を注いだ幾多の著述の中で，その最後を飾るに足る研究が，カロライナ・ベイ の地形発達を説明したこの書である.ジョンスンはショーア・プロセスの海岸地形 、一般論に引きつづき,ニューイングランド・アカディアの海岸地形誌を書き，コロ ンビア地形研究の 2 冊として, アパラチア山地の地形発達と海中谷に関する本を出 すまでに，地形学に関係がない書物に筆を取つていない. 第 1 次世界大戦の直後に 出たバットルフィールズは, 要るに応用地形学であり, フランスで公にしたアメリ カの景観も，北米の地形解説である.

地形研究の方法論としては，アメリカ地質学会のブレティンに載せた，その絶筆 
と見るべき海岸段丘の対比があり，ジャーナル・オヴ・ジオロジーで論じた，科学 研究における分析的方法がある外に，ジャ一ナル・オヴ・ジオモーフォロジーの 5 巻 20 冊の大半に執筆した，多数の論評があつて，その論理的な精神性師のデー ヴィスに劣らず，考察の細密な点ではその上にあつた.コリレーション・オヴ・マ リン・テレーセスの論文などは，地質学者が陥りやすいう法的誤診に対し，警世の 文字として貴重なものと思う。本書は著者の研究態度に関する主張を，カロライ ナ・ベイの奇妙な形態について実証したものであり，その研究手段は巧妙というよ， りも，あくまで質実であり，少しの「けれん」を許さないものである. 空中写真 を善用して新機軸を出し，気象要素を綿密に検べた点でも，今後の研究者が範とす るに足りる。

ベイと俗称をもつた地形は，アトランティック・コースタル・プレーンの低地に ある，浅い盆地の群であり，その底は湿原であるが，空中写真では長軸を平行にし て並ふ隋円形の斑点となり，その形状と配列の模様から，メルトン及シュリヴァー の隕石群による傷痕の説が産れた。この機構が無理なことに就ては, 正面から批判 が行われる. よく観察するとほぼ東南に延びたベイの東南側には, 砂丘の縁がある. ラグーンの水面が砂のスピットに区劃され，この形になるというクックの解釈もあ つたし，石灰質の地層の上に，溶蝕による窪地が生じたというスミスの説明もある. 著者の考は 1934 年に簡単な形で公表した。複雑生因説 (Hypothesis of complex origin）であり，噴泉——溶蝕——湖成——風成——憶説 (The artesian-solutionlacustrineaelian hypothesis) である.

この憶説によつて正当に解釈され，他の諸説に矛盾する事実の主なものは次のご とくである. ベイの棈円率は面積と共に著しくなる，砂丘の縁は時として二重また は三重である.ベイの形はしばしば一部分で重なり合い切り合う：その形態は所に よつて卵形となる. 不規則な形の乼みから完全な棈円まで，あらゆる段階で形態の 䔟り変りが見られ，大きさには大差があつて，長さ数百フィートからの一マイルに 及ふ。. 砂丘は一様に白色また淡黄色の石英砂より成る.ベイに流入し時にベイから 流出する流れがあり，地下水と噴泉の力で，表土が掘られた形跡は明らかである.

最初に噴泉時期があり，海岸平野が開析される前には，特に地表の湧泉は多かつ た. その営力によつて砂層は崩れ，浅い池の形成が始まる. 次の溶蝕時泥灰期には 岩や柔かい石灰岩があり，浅いドリーネとの中間形が沢山ある.それらは地下水の ス口となり，ベイの位置は出口に相当する．湖成時期に相応する現象として；前に は湖沼が多数あり，その底に泥崖が堆積した。気成時期の変化として，湖岸には砂 丘ができ，その場所は卓越風の風下にあたる側である. 湖の波で侵蝕される湖岸の 形は，同じく主風の方向に延びた楕円形となる・同時に噴泉の位置は上方に移動し て行くからである. それらの方向が少し違うから，エリプスの形も実は非対称を示 
し，一方の曲率が大きいことが多い.

かくしてカロライナ・ベイの地形は次のような定義のものとなる，それは多少卵 形の浅い盆地であり，多くは北西から南東に向つて延長し，一般に湿地または湖沼 となつているが，時として乾いた平野となる．それらは噴泉の掘さく作用によつて 生じ；溶蝕の力がこれを助けるが，両方の作用が独立に働くこともある. 多くの場 合には曾て存在した湖面の波が，湖岸を侵蝕してその形を滑らかにし，岸にちかく 浜堤や砂洲を形成し，時には風の作用が働いて，風下の側に砂丘のへりを造る.上 記の定義は非常に複雑であるが，ベイの本質はかくも複雑なものであり，その性質 は或る範囲の中で変化を示すのである. 自然の現象が時に複雑かつ神秘な形を呈す るならば，われわれはその複雑さを忠実に記録し，その神秘を解くために，最善を つくすの外はない，だから上述の定義は，泗形盆地の本性を，出来るだけ簡潔かつ 正確に記したものといい得るであろう.

辻村 太郎

\section{国際地理学連合 : 内陸熱帯アフリカにおける天然凅源}

と食糧と人口（55 年マケレレ・シンポジアム）

\section{International Geographical Union : Natural Resources,} Food and Population in Inter-Tropical Africa

Report of A Symposium at Makerere College, Sept, $\$ 1955.104$ p. London, 1956. 5s

IGU では 3〜4 年に 1 回 Congress を開いているが，その中間に開かれた第 1 回 が，この東アフリカ，ウガンダのシンポジアムである. 報告書は会議の参加者・日 程その他を示しているが，主要部分は発表された論文の要約 64 頁と見学旅行地の， 記述 24 頁である.

論文の総数は 21 ，討議に使われた 5 日間の報告を全部ふくんでいる．ウガンダ ・ 赤道アフリカ・スダン・ケニア・西アフリカ・黄金海岸・ナイゼリア・シエラレオ ネ・マウリタニア等の各地について，自然，人口・農業・集落・交通などに関する 論文が大部分である.もっとも短いのは半頁にもみたぬが，多くは2〜6頁である。 図もいくつか入っているが，論文としては簡単すぎるしかしアフリカの地理につ いて珍らしいことが多い（たとえば副会長 O’ Ribeiro（リスボン）の西アフリカ の集落の集散と農耕，Morgan の南ナイゼリアの耕地を集落，Protheo の北ナイゼ リアの人口の移動，Lebon の中央スダンの経済開発など，もっと俸しい研究を読 んでみたいという念を起させるに十分である. 本書の編集者であり，IGU の会長 である L. D. Stamp および 2 人の世界土地利用調査に関するアフリカへの適用に ついての記述がある。

見学旅行の案内記は，討議会の午後のものと，後のウガンダ領内，5日間 562 マ イルのものについてである.（石田） 